\title{
Assessment of Genetic Relationship among Landraces of Bangladeshi Ridge Gourd (Luffa acutangula Roxb.) Using RAPD Markers
}

\author{
S. Hoque ${ }^{1}$ and M. G. Rabbani \\ Department of Horticulture, Bangladesh Agricultural University, Mymensingh-2002, Bangladesh
}

Received 28 January 2009, accepted in revised form 29 May 2009

\begin{abstract}
Information on genetic relatedness among ridge gourd (Luffa acutangula) genotypes from Bangladesh is currently not reported. Twenty eight accessions collected from different parts of Bangladesh were studied using random amplified polymorphic DNA (RAPD) technique. Four selected decamer primers, out of sixteen screened, could generate a total of 27 RAPD fragments of which 22 were polymorphic (81.5\%). The bands ranged from 50 to $1500 \mathrm{bp}$ in size. Genetic variation statistics for all loci estimated the average gene diversity (h) value as 0.278 and the Shannon's Information Index (I) as 0.415. Dendrogram based on unweighted pair-group method with arithmetic averages (UPGMA) segregated the accessions into five clusters. Cluster III was the largest with 13 members followed by cluster II, V, I and IV with 6, 4, 3 and 2 members, respectively. Accession LA27 and LA29 were found very close to each other with the highest inter-variety similarity index $(96.05 \%)$ and the lowest genetic distance (0.077); whereas accession LA40 and LA72 were more distant to each other with the lowest inter-variety similarity index (44.43\%) and the highest genetic distance (0.73). A DNA extraction method has been standardized. The marker was found to be useful tool for assessing genetic variations in Luffa acutangula.
\end{abstract}

Keywords: Genetic relationship; Germplasm; Ridge gourd; Luffa acutangula; RAPD.

C을 2009 JSR Publications. ISSN: 2070-0237 (Print); 2070-0245 (Online). All rights reserved.

DOI: 10.3329 /jsr.v1i3.1968

J. Sci. Res. 1 (3), 615-623 (2009)

\section{Introduction}

Ridge gourd (Luffa acutangula Roxb.) is an important member of the family Cucurbitaceae grown in Bangladesh as a year-round vegetable. It is nutritionally rich in vitamin $\mathrm{A}, \mathrm{C}$ and $\mathrm{Fe}$ [1]; and has a considerable medicinal importance. Its abortifacient, antitumor, ribosome inactivating and immunomodulatory activities were reported earlier [2-4]. Recently it has gained attention from the nutritionists due to the presence of antioxidant (free radical scavenging-FRS) activity [5]. Effectiveness of its extract as larvicide [6] and its seed oils as grain protectant against certain insects [7] are not very far discoveries. Many wild relatives of this crop are grown in Bangladesh. So far, 106 local

\footnotetext{
${ }^{1}$ Corresponding author: babu_hort05@yahoo.com
} 


\section{Assessment of Genetic}

landraces were reported [8]. The average yield of the crop in Bangladesh, which was about $1.83 \mathrm{mt}$ per acre in the year 2007-2008 [9], indicates low yield potentiality of the cultivars. The lack of high yielding variety, among many reasons, is an important one for such a low yield of this crop in Bangladesh. In a crop improvement programme, genetic diversity is one of the important tools to quantify genetic variability in both cross and self pollinated crops [10]. Polymerase chain reaction (PCR) technology had led to the development of several novel genetic assays based on selective DNA amplification. RAPD assay detects nucleotide sequences of polymorphic DNA using only a single primer of arbitrary nucleotide sequence. This technique always allows the examination of genomic variations without prior knowledge of DNA sequences, and is especially useful for revealing variations in a species with low genetic variability. In spite of some weaknesses, the relative case and speed, the high degree of polymorphism and the virtually inexhaustible pool of possible genetic markers make the technique advantageous over other molecular approaches. Growing interest to this vegetable crop (ridge gourd) was achieved through the studies on its constituents, but no systematic research on molecular basis has so far been done to evaluate the genetic potentialities of the available germplasm with a view to releasing modern varieties to meet up increasing demands to come. Under such circumstances, this study was conducted to identify variations within each of the ridge gourd germplasm under study, so that genetic relationship can be established at gene level using RAPD markers.

\section{Materials and Methods}

\subsection{Plant materials}

A total of 28 ridge gourd germplasm were used in this study. The materials were collected from different parts of Bangladesh by the Dept of Horticulture, Bangladesh Agricultural University, Mymensingh under a USDA-funded (BG-ARS-108) project entitled CVFB (Collection, Evaluation, Conservation and Utilization of Landraces and Wild Relatives of Some Important Vegetables and Fruits of Bangladesh).

\subsection{Genomic DNA isolation}

The total genomic DNA was isolated from young leaf tissue following the procedure described by Murray and Thompson [11]. The purity of DNA was confirmed by $1 \%$ agarose gel electrophoresis and the quantity was estimated by spectrophotometer at a wavelength of $260 \mathrm{~nm}$ using the Spectronic ${ }^{\circledR}$ Genesis $^{\mathrm{TM}}$ (Spectronic Instruments Inc., USA). The final DNA concentration of each sample was adjusted to $25 \mathrm{ng} / \mu \mathrm{l}$.

\subsection{DNA amplification}

After screening of 16 random primers from Operon Technologies Inc. (Alameda, California, USA), 4 decamers of oligonucleotides (OPA-04, OPA-07, OPC-02 and OPC- 
06) produced clear and unambiguous bands were used for DNA amplification adopting the procedure of William et al. [12] with some modifications. Amplification reactions were carried out in a volume of $10 \mu \mathrm{l}$ containing $10 \mathrm{mM}$ of dNTPs (deoxynucleotide triphosphate) $(2.5 \mathrm{mM}$ each), $1 \mu \mathrm{l}$ of $(10 \times)$ Taq DNA polymerase buffer, 1 unit (U) of Taq DNA polymerase (Genei Pvt. Ltd., Bangalore, India), $0.5 \mu \mathrm{M}$ of 10 mer primer, 100 ng $(4 \mu \mathrm{l})$ of genomic DNA and a suitable amount of sterile deionized water. Amplifications were performed in an oil-free thermal cycler (Master Cycler Gradient, Eppendorf) programmed for an initial denaturation at $94^{\circ} \mathrm{C}$ for $5 \mathrm{~min}, 40$ cycles of $30 \mathrm{sec}$ denaturation at $94^{\circ} \mathrm{C}, 30 \mathrm{sec}$ annealing at $40^{\circ} \mathrm{C}$ and $1 \mathrm{~min}$ extension at $72^{\circ} \mathrm{C}$, followed by final extension for $10 \mathrm{~min}$ at $72^{\circ} \mathrm{C}$. Reactions were held at $4^{0} \mathrm{C}$ after completion of cycling. The amplified products plus loading dye were subjected to horizontal gel electrophoresis using $1.4 \%$ agarose gel in $1 \times$ TBE ( $89 \mathrm{mM}$ Tris-Borate, $3 \mathrm{mM}$ EDTA) buffer at $100 \mathrm{~V}$ for $1 \mathrm{hr}$ using Genei Submarine Electrophoresis System. We used pUC18 marker and 100 bp DNA ladder (Genei Pvt. Ltd., Bangalore, India) as molecular size marker. The ethidium bromide stained gels were documented using UV Transilluminator (UVP Ltd., Trinity hall estate, Cambridge, UK).

\subsection{Data analysis}

All distinct RAPD bands were given identification numbers according to their position on gel and scored visually on the basis of their presence (1) or absence (0) separately for each individual and each primer. The scores were then pooled to construct a single data matrix. This was used for estimating polymorphic loci, Nei's [13] gene diversity, Shannon's Information index [14] and the UPGMA dendrogram of the populations based on Nei's [15] genetic distances using the POPGENE (Version 1.31) [16] software package.

The similarity index values (SI) between the RAPD profiles of any two individuals on the same gel were calculated from RAPD markers according to the following formula:

Similarity index $(\mathrm{SI})=2 N_{x y} /\left(N_{x}+N_{y}\right)$

where $N_{x}=$ the total number of fragments detected in individual ' $x$ '; $N_{y}=$ the total number of fragments shown by individual ' $y$ ' and $N_{x y}=$ the number of fragments shared by individuals ' $x$ ' and ' $y$ ' [17]. Between population similarity (Sij) was calculated as the average similarity between randomly paired individuals from populations $i$ and $j[18]$.

\section{Results and Discussion}

\subsection{Polymorphism}

A considerable level of variability was observed among different landraces. Fig. 1 shows the RAPD profiles generated by the primer OPC- 02 across 28 ridge gourd germplasm. A total of 27 bands were generated by selected four decamer primers of which 22 were 


\section{Assessment of Genetic}

polymorphic $(81.5 \%)$. Primer OPC-02 showed the highest polymorphism (100\%) with the maximum number of fragments (8) whereas Primer OPA-07 showed the lowest (71.5\%). Other two primers (OPA-04 and OPC-06) produced equal (75\%) polymorphism, though the later gave the minimum number of bands (4). The average number of DNA bands amplified by each primer was 6.75 ranging from 50-1500 bp in size (Table 1).
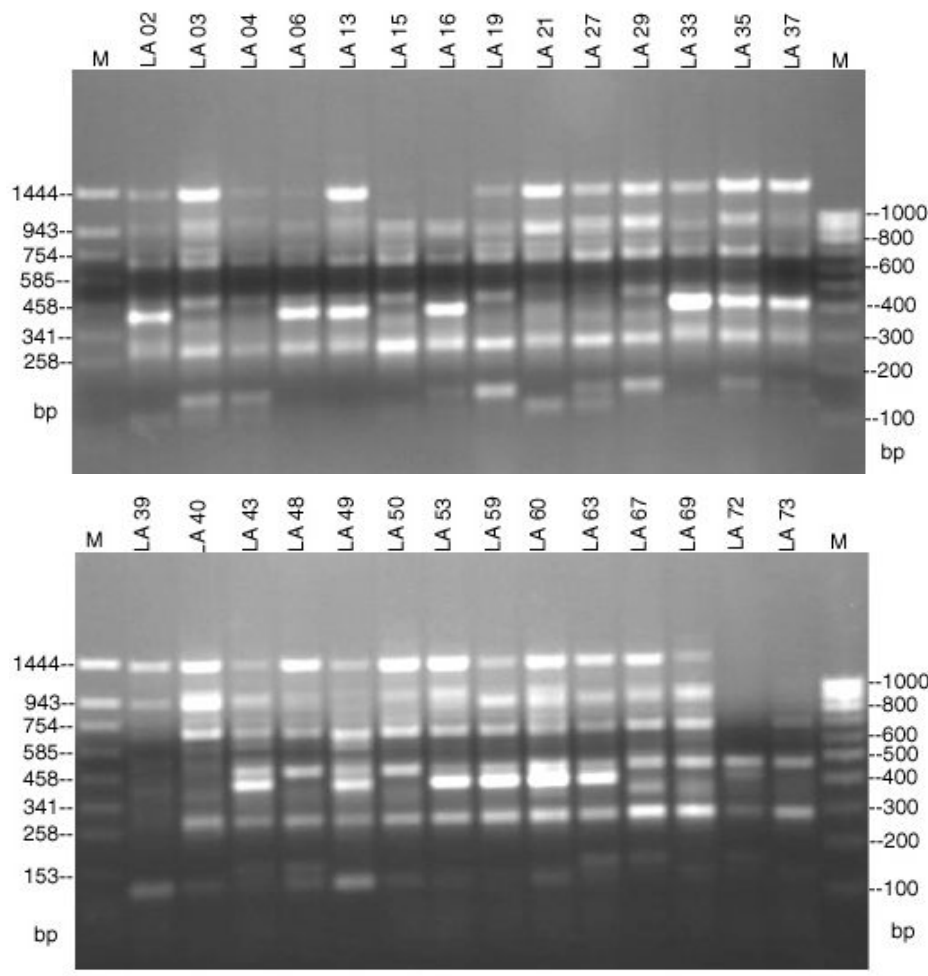

Fig. 1. RAPD marker profiles of 28 ridge gourd germplasm generated by primer OPC- 02 in $1.4 \%$ agarose gel. (M: molecular weight marker100 bp DNA ladder on right side and $\mathrm{P}^{\mathrm{UC}}$ on the left)

Table 1. RAPD primers used to detect polymorphism, number of bands for polymorphism and size of the amplified fragments observed in ridge gourd germplasm from Bangladesh.

\begin{tabular}{lccccc}
\hline $\begin{array}{c}\text { Primer } \\
\text { code }\end{array}$ & $\begin{array}{c}\text { Primer sequence } \\
\left(5^{\prime}-3^{\prime}\right)\end{array}$ & $\begin{array}{c}\text { Number of } \\
\text { scorable } \\
\text { bands }\end{array}$ & $\begin{array}{c}\text { Number of } \\
\text { polymorphic } \\
\text { markers }\end{array}$ & $\begin{array}{c}\text { Percent } \\
\text { poly- } \\
\text { morphism }\end{array}$ & $\begin{array}{c}\text { Size ranges } \\
\text { (bp) }\end{array}$ \\
\hline OPA-04 & AATCGGGCTG & 8 & 6 & 75 & $150-1500$ \\
OPA-07 & GAAACGGGTG & 7 & 5 & 71.5 & $50-1500$ \\
OPC-02 & GTGAGGCGTC & 8 & 8 & 100 & $100-1450$ \\
OPC-06 & GAACGGACTC & 4 & 3 & 75 & $200-1500$ \\
\hline Total & & 27 & 22 & & \\
\hline
\end{tabular}




\begin{tabular}{|c|c|c|}
\hline Average & 6.75 & 81.5 \\
\hline
\end{tabular}

\subsection{Genetic variation and similarity matrix}

Genetic variation statistics for all loci estimated the mean for Nei's gene diversity (h) value of 0.278 and that for Shannon's information Index (I) of 0.415. The loci OPA04-5, OPA04-6, OPA07-2, OPA07-6 and OPC06-3 were monomorphic showing nil $\mathrm{h}$ and I values. The maximum variation was exhibited by the locus OPA07-3 with $\mathrm{h}$ and I values of 0.5 and 0.693 , respectively (Table 2). A similarity matrix based on the proportion of shared RAPD fragments was used to establish the level of relatedness between the germplasm. Pair-wise estimates of Similarity Indices $\left(S_{i j}\right)$ ranged from $44.43 \%$ in Accession LA40-LA72 pair to $96.05 \%$ in Accession LA27-LA29 pair (Table 3).

Table 2. Summary of genetic variation statistics for all loci.

\begin{tabular}{ccclcc}
\hline Locus & $\begin{array}{c}\text { Nei's gene } \\
\text { diversity } \\
\text { (h) }\end{array}$ & $\begin{array}{c}\text { Shannon's } \\
\text { Information } \\
\text { index (I) }\end{array}$ & Locus & $\begin{array}{c}\text { Nei's gene } \\
\text { diversity } \\
(\mathrm{h})\end{array}$ & $\begin{array}{c}\text { Shannon's } \\
\text { Information } \\
\text { index (I) }\end{array}$ \\
\hline OPA04-1 & 0.459 & 0.652 & OPC02-1 & 0.245 & 0.410 \\
OPA04-2 & 0.490 & 0.683 & OPC02-2 & 0.133 & 0.257 \\
OPA04-3 & 0.490 & 0.683 & OPC02-3 & 0.133 & 0.257 \\
OPA04-4 & 0.191 & 0.341 & OPC02-4 & 0.133 & 0.257 \\
OPA04-5 & 0.000 & 0.000 & OPC02-5 & 0.337 & 0.520 \\
OPA04-6 & 0.000 & 0.000 & OPC02-6 & 0.069 & 0.154 \\
OPA04-7 & 0.408 & 0.598 & OPC02-7 & 0.459 & 0.652 \\
OPA04-8 & 0.408 & 0.598 & OPC02-8 & 0.408 & 0.598 \\
OPA07-1 & 0.477 & 0.670 & OPC06-1 & 0.069 & 0.154 \\
OPA07-2 & 0.000 & 0.000 & OPC06-2 & 0.191 & 0.341 \\
OPA07-3 & 0.500 & 0.693 & OPC06-3 & 0.000 & 0.000 \\
OPA07-4 & 0.497 & 0.691 & OPC06-4 & 0.459 & 0.652 \\
OPA07-5 & 0.477 & 0.670 & & & \\
OPA07-6 & 0.000 & 0.000 & Mean & 0.278 & 0.415 \\
OPA07-7 & 0.477 & 0.670 & St. Dev. & 0.197 & 0.267 \\
\hline
\end{tabular}

Table 3. Summary of band-sharing based on similarity indices, $S_{i j}(\%)$ among individuals of 28 ridge gourd germplasm from Bangladesh.

\begin{tabular}{ccccccccccc}
\hline Pop & LA02 & LA03 & LA04 & LA06 & LA13 & LA15 & LA16 & LA19 & LA21 & LA27 \\
\hline LA02 & $* * *$ & & & & & & & & & \\
LA03 & 84.50 & $* * *$ & & & & & & & & \\
LA04 & 77.40 & 93.08 & $* * *$ & & & & & & & \\
LA06 & 81.00 & 85.65 & 88.10 & $* * *$ & & & & & & \\
LA13 & 86.15 & 74.00 & 69.05 & 80.95 & $* * *$ & & & & & \\
LA15 & 80.00 & 67.63 & 69.25 & 81.08 & 92.73 & $* * *$ & & & & \\
LA16 & 73.30 & 89.50 & 90.18 & 81.25 & 75.60 & 72.75 & $* * *$ & & & \\
LA19 & 92.58 & 80.05 & 71.68 & 79.75 & 84.18 & 83.33 & 76.43 & $* * *$ & & \\
LA21 & 73.35 & 85.83 & 85.33 & 80.53 & 82.93 & 75.68 & 88.38 & 72.95 & $* * *$ & \\
LA27 & 79.75 & 95.83 & 92.73 & 84.60 & 72.95 & 66.58 & 89.15 & 79.00 & 90.00 & $* * *$ \\
LA29 & 75.60 & 91.88 & 93.28 & 88.48 & 70.43 & 69.95 & 87.48 & 78.03 & 83.93 & 96.05 \\
LA33 & 73.93 & 78.15 & 79.78 & 91.68 & 86.68 & 89.40 & 79.18 & 77.25 & 86.25 & 77.10 \\
LA35 & 79.35 & 82.55 & 79.28 & 87.35 & 81.43 & 79.18 & 79.03 & 86.68 & 81.28 & 81.50 \\
LA37 & 74.53 & 86.43 & 88.98 & 92.58 & 79.50 & 80.58 & 81.58 & 75.85 & 83.93 & 85.83
\end{tabular}


\begin{tabular}{lllllllllll} 
LA39 & 80.68 & 81.43 & 73.48 & 80.90 & 69.40 & 61.60 & 66.80 & 76.10 & 76.35 & 82.93 \\
\hline
\end{tabular}

Table 3. Continued

\begin{tabular}{ccccccccccc}
\hline Pop & LA02 & LA03 & LA04 & LA06 & LA13 & LA15 & LA16 & LA19 & LA21 & LA27 \\
\hline LA40 & 60.95 & 69.45 & 75.60 & 78.93 & 65.85 & 65.85 & 66.78 & 58.45 & 74.13 & 72.63 \\
LA43 & 80.00 & 67.38 & 61.70 & 65.28 & 81.25 & 74.50 & 66.68 & 83.30 & 72.78 & 70.55 \\
LA48 & 73.33 & 62.40 & 62.58 & 66.08 & 68.58 & 67.63 & 55.95 & 72.35 & 62.08 & 66.15 \\
LA49 & 92.30 & 83.90 & 80.00 & 71.43 & 81.43 & 75.00 & 75.90 & 83.93 & 81.08 & 83.55 \\
LA50 & 78.75 & 87.30 & 83.80 & 87.30 & 74.50 & 74.18 & 82.75 & 78.33 & 78.28 & 82.40 \\
LA53 & 87.83 & 88.68 & 80.65 & 88.08 & 81.43 & 74.98 & 80.05 & 83.65 & 81.43 & 83.93 \\
LA59 & 75.58 & 84.15 & 79.78 & 83.35 & 77.10 & 70.35 & 79.18 & 74.60 & 85.58 & 87.90 \\
LA60 & 74.85 & 83.33 & 83.75 & 83.50 & 77.85 & 70.85 & 85.90 & 74.78 & 90.18 & 87.08 \\
LA63 & 78.10 & 77.50 & 72.45 & 72.20 & 91.25 & 84.00 & 79.35 & 84.85 & 85.83 & 79.40 \\
LA67 & 78.15 & 89.58 & 85.83 & 85.58 & 73.08 & 72.60 & 85.58 & 85.23 & 81.65 & 89.23 \\
LA69 & 87.58 & 79.75 & 72.00 & 71.73 & 80.90 & 74.45 & 76.40 & 87.30 & 73.08 & 75.58 \\
LA72 & 73.40 & 66.40 & 58.33 & 60.83 & 70.00 & 67.60 & 65.83 & 76.93 & 63.00 & 66.05 \\
LA73 & 59.70 & 68.83 & 64.18 & 66.68 & 60.43 & 57.73 & 66.68 & 58.45 & 69.13 & 72.00 \\
\hline
\end{tabular}

Table 3. Continued

\begin{tabular}{cccccccccc}
\hline Pop & LA29 & LA33 & LA35 & LA37 & LA39 & LA40 & LA43 & LA48 & LA49 \\
\hline LA29 & $* * *$ & & & & & & & & \\
LA33 & 80.53 & $* * *$ & & & & & & & \\
LA35 & 84.85 & 89.75 & $* * *$ & & & & & & \\
LA37 & 89.58 & 91.15 & 87.35 & $* * *$ & & & & & \\
LA39 & 77.63 & 73.83 & 79.53 & 74.45 & $* * *$ & & & & \\
LA40 & 76.20 & 77.50 & 69.95 & 79.28 & 73.03 & $* * *$ & & & \\
LA43 & 69.03 & 68.45 & 74.48 & 63.35 & 66.78 & 74.18 & $* * *$ & & \\
LA48 & 69.58 & 63.68 & 69.73 & 64.58 & 66.25 & 70.98 & 79.40 & $* * *$ & \\
LA49 & 79.00 & 68.93 & 74.78 & 74.00 & 71.55 & 64.03 & 83.30 & 76.90 & $* * *$ \\
LA50 & 86.23 & 85.23 & 85.40 & 79.33 & 77.90 & 74.00 & 68.57 & 68.35 & 73.33 \\
LA53 & 82.93 & 85.58 & 91.15 & 86.18 & 83.90 & 72.78 & 75.50 & 70.45 & 83.98 \\
LA59 & 86.83 & 80.95 & 81.43 & 81.83 & 79.58 & 83.75 & 81.68 & 77.73 & 79.15 \\
LA60 & 81.85 & 81.43 & 75.60 & 75.70 & 80.10 & 77.45 & 76.43 & 66.93 & 73.35 \\
LA63 & 76.90 & 77.93 & 74.13 & 79.18 & 65.30 & 65.80 & 81.10 & 68.75 & 81.28 \\
LA67 & 92.73 & 83.18 & 93.05 & 85.58 & 77.63 & 68.18 & 72.25 & 67.50 & 77.10 \\
LA69 & 74.58 & 69.23 & 74.80 & 68.10 & 67.25 & 54.70 & 78.83 & 70.18 & 86.98 \\
LA72 & 64.50 & 58.33 & 64.43 & 57.78 & 53.75 & 44.43 & 67.73 & 63.40 & 72.75 \\
LA73 & 70.38 & 64.28 & 65.28 & 65.95 & 60.10 & 77.08 & 74.18 & 64.28 & 63.00 \\
\hline
\end{tabular}

Table 3. Continued

\begin{tabular}{cccccccccc}
\hline Pop & LA50 & LA53 & LA59 & LA60 & LA63 & LA67 & LA69 & LA72 & LA73 \\
\hline LA50 & $* * *$ & & & & & & & & \\
LA53 & 85.80 & $* * *$ & & & & & & & \\
LA59 & 81.08 & 87.73 & $* * *$ & & & & & & \\
LA60 & 81.25 & 78.08 & 89.75 & $* * *$ & & & & & \\
LA63 & 69.95 & 73.10 & 77.25 & 78.28 & $* * *$ & & & & \\
LA67 & 88.88 & 85.48 & 79.75 & 79.78 & 76.90 & $* * *$ & & & \\
LA69 & 74.45 & 79.75 & 70.68 & 70.58 & 80.58 & 81.38 & $* * *$ & & \\
LA72 & 67.60 & 65.05 & 59.85 & 60.28 & 70.50 & 71.33 & 85.58 & $* * *$ & \\
LA73 & 68.45 & 71.33 & 82.50 & 72.78 & 60.80 & 63.60 & 54.28 & 68.18 & $* * *$ \\
\hline
\end{tabular}

\subsection{Cluster analysis}


Pair-wise comparisons of Nei's genetic distance (GD) between ridge gourd germplasm were calculated from combined data for the four primers. The highest GD (0.73) was observed between Accession LA40 and LA72, whereas the lowest (0.077) was between Accession LA27 and LA29. The UPGMA dendrogram based on Nei's genetic distance [15] segregated the populations into 5 clusters (Fig. 2). Cluster III was the largest comprising 13 populations followed by cluster II, V, I and IV with 6, 4, 3 and 2 members respectively.

A propitious natural environment for ridge gourd cultivation prevails in Bangladesh. It is a very common homestead vegetable consumed by wide range of people. Despite the nutritional as well as medicinal importance of the vegetable, information on the genetic background of this species is very scarce. We are the first in Bangladesh to report genetic variability among available landraces of Luffa acutangula with the help of randomly amplified polymorphic DNA (RAPD) markers. In the present study, RAPD technique has been found to be suitable in revealing genetic variability and relatedness among collected landraces of ridge gourd. It is predicted that the DNA fragments shared by two closely related individuals of a species are allelic while the fragments of equal sizes may have originated from a non-allelic genomic region [19]. The use of many RAPD primers may provide large number of species-specific RAPD markers for the analysis [20].

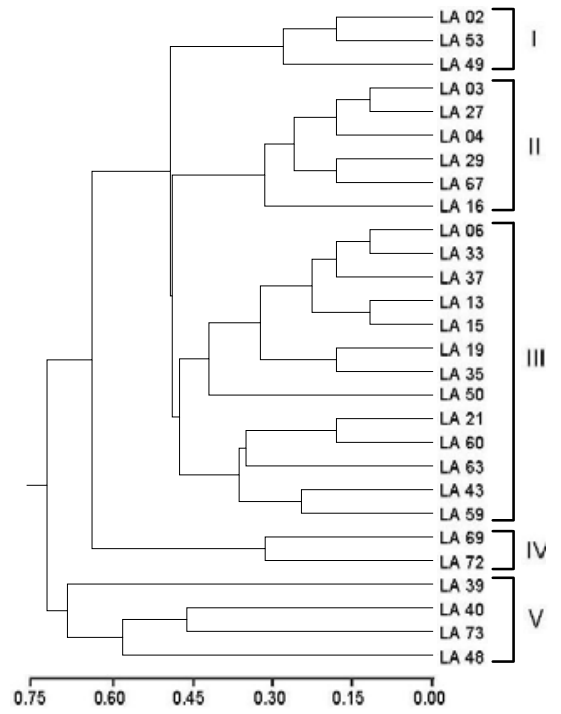

Fig. 2. Unweighted pair group method of arithmetic mean (UPGMA) dendrogram based on Nei's [15] genetic distance between 28 ridge gourd germplasm according to RAPD analysis.

The proportion of polymorphic loci obtained in the present study was lower (81.5\%) than that reported in teasle gourd-Momordica dioica Roxb. (95\%) [21] but higher than that in bitter gourd-Momordica charantia L. (36.5\%) [22], Cucurbita maxima (57\%) [23] and melon-Cucumis melo (73\%) [24]. Like the proportion of polymorphic loci, Nei's gene diversity and Shannon's information index were also higher, and that was expected because the samples were collected from different parts of the country covering the 
maximum agro-ecological zones (AEZs) of Bangladesh. Relatively lower Similarity indices (44.43-96.05\%) as compared to water melon (92-99.6\%) [25] also indicated high genetic variation among collected germolasm of ridge gourd. The UPGMA dendrogram based on genetic distance (GD) grouped the populations into 5 clusters. Relatively high GD value (0.73) suggested that RAPD-based diversity assessments in this germplasm were generally consistent. The Luffa acutangula accessions examined were genetically distinct, and these differences provided for the development of strategies for genetic analyses and crop improvement in this species [26]. It also indicated that the genetic relationships identified using RAPD markers were highly concordant [27].

RAPD markers have been proved as effective tools to monitor the genetic variation in different organisms. Using only four primers and 28 samples, the present study revealed a remarkable level of genetic variability in Luffa acutangula. A more definite conclusion, however, may be reached with larger samples including all AEZ (if possible to collect) of Bangladesh with faster evolving molecular markers such as microsatellite loci. The level of genetic variation provides the raw material for the selective improvement of a stock for sustainable agriculture production. Through this study, we have revealed, for the first time, the genetic relationship among available landraces of cultivated ridge gourd $(L$. acutangula) in Bangladesh. The result of present study can be used as a baseline for further study with a view to improving the crop.

\section{Acknowledgement}

The authors wish to acknowledge the authority of CVFB project funded by USDA for providing experimental materials and necessary facilities to conduct the present study.

\section{References}

1. K. S. Yawalkar, Vegetable Crops of India. $3^{\text {rd }}$ ed. (Agric. Horticultural Publishing House, Nagpur, 1985) pp. 166-170.

2. H. W. Yeung, W. W. Li, and T. B. Ng, Int. J. Pept. Protein Res. 38 (1), 15 (1991).

3. T. B. Ng, W. Y. Chan, and H. W. Yeung, Gen. Pharmacol. 23 (4), 579 (1992). doi:10.1016/0306-3623(92)90131-3

4. H. Wang and T. B. Ng, Life Sci. 70 (8), 899 (2002). doi:10.1016/S0024-3205(01)01466-7

5. N. M. Ansari, L. Houlihan, B. Hussain, and A. Pieroni, Phytother. Res. 19 (10), 907 (2005). doi:10.1002/ptr.1756

6. K. Prabakar and A. Jebanesan, Bioresour. Technol. 95, 113 (2004). doi:10.1016/j.biortech.2003.05.001

7. D. Mishra, A. K. Shukla, K. K. Tripathi, A. Singh, A. K. Dixit, and K. Singh, J. Oleo Sci. 56, 1(2007). http://www.jstage.jst.go.jp/article/jos/56/1/1/_pdf

8. M. G. Rabbani, USDA-Bangladesh collaborative research-CVFB-Annual Research Report. Dept. of Horticulture, Bangladesh Agricultural University, Mymensing (2007) p. 35.

9. BBS (Bangladesh Bureau of Statistics), Monthly Statistical Bulletin-Bangladesh (August), Planning Division, Ministry of Planning, GOB. p. 66 (2008).

10. P. Gaur, C. Gupta, and H. Kishore, Euphytica 27, 361 (1978). doi:10.1007/BF00043160

11. M. G. Murray and W. F. Thompson, Nucl. Acids Res. 8 (19), 4321 (1980). doi:10.1093/nar/8.19.4321 
12. J. G. K. Williams, A. R. Kubelik, K. J. Livak, J. A. Rafalski, and S. V. Tingey, Nucleic Acids Res. 18, 6531 (1990). doi:10.1093/nar/18.22.6531

13. M. Nei, Proc. Nat. Acad. Sci. USA 70, 3321 (1973). doi:10.1073/pnas.70.12.3321

14. R. C. Lewontin, Evol. Biol. 6, 381 (1972).

15. M. Nei, Am. Nat. 106, 283 (1972). doi:10.1086/282771

16. F. C. Yeh, R. C. Yang, and T. Boyle, POPGENE, version 1.31. Microsoft windows based freeware for population genetic analysis. University of Alberta, Canada (1999) http://www.ualberta.ca/ fyeh.

17. M. Lynch, Mol. Biol. Evol. 7, 478 (1990).

18. M. Lynch, Analysis of population genetic structure by DNA fingerprinting. In: DNA fingerprinting approaches and applications, T. G. Burke, A. Dolf, J. Jeffreys and R. Wolf (Eds.). (Basel, Switzerland, 1991) pp. 113-126.

19. K. Kazan, J. M. Manners, and D. F. Cameron, Genome 36, 50 (1993). doi:10.1139/g93-007

20. J. M. Bidochka, M. A. Mcdonald, R. J. St. Leger, and D. W. Roberts, Curr. Genet. 25, 107 (1994). doi:10.1007/BF00309534

21. M. G. Rasul, M. Hiramatsu, and H. Okubo, Scientia Horticulturae 111 (3), 271 (2007). doi:10.1016/j.scienta.2006.10.023

22. S. S. Dey, A. K. Singh, D. Chandel, and T. K. Behera, Scientia Horticulturae 109 (1), 21 (2006). doi:10.1016/j.scienta.2006.03.006

23. M. Ferriol, M. B. Pico, and F. Nuez, Genet. Resour. Crop Evol. 50 (3), 227 (2003). doi:10.1023/A:1023502925766

24. J. Garcia-Mas, M. Oliver, H. Gomez-Paniagua, and M. C. de Vicente, Theor. Appl. Genet. 101, 860 (2000). doi:10.1007/s001220051553

25. A. Levi, C. E. Thomas, T. C. Wehner, and X. P. Zhang, J. Hort. Sci. 36 (6), 1096 (2001). http://cuke.hort.ncsu.edu/cucurbit/wehner/articles/art095.pdf

26. T. K. Behera, A. K. Singh, and Jack.E. Staub, Scientia Horticulturae 115 (3), 209 (2008). doi:10.1016/j.scienta.2007.08.013

27. F.Y. Zhuang, J. F. Chen, J. E. Staub, and C. T. Qian, Plant Breed. 123, 167 (2004). doi:10.1046/j.1439-0523.2003.00889.x 